Reading Joshua as Christian Scripture 
Journal of Theological Interpretation Supplements

MurRay RAE

University of Otago, New Zealand

Editor-in-Chief

1. Thomas Holsinger-Friesen, Irenaeus and Genesis: A Study of Competition in Early Christian Hermeneutics

2. Douglas S. Earl, Reading Joshua as Christian Scripture 


\section{Reading Joshua as Christian Scripture}

Douglas S. EARL

Winona Lake, Indiana

EISENBRAUNS

2010 


\section{Copyright (C) 2010 Eisenbrauns}

All rights reserved.

Printed in the United States of America

www.eisenbrauns.com

\section{Library of Congress Cataloging-in-Publication Data}

Earl, Douglas S.

Reading Joshua as Christian scripture / Douglas S. Earl.

p. $\quad \mathrm{cm}$. - (Journal of theological interpretation supplements ; 2)

Includes bibliographical references and index.

ISBN 978-1-57506-701-8 (pbk. : alk. paper)

1. Bible. O.T. Joshua-Criticism, interpretation, etc. I. Title.

BS1295.52.E27 2010

$222^{\prime} .206-\mathrm{dc} 22$

The paper used in this publication meets the minimum requirements of the American National Standard for Information Sciences-Permanence of Paper for Printed Library Materials, ANSI Z39.48-1984.@ ${ }^{\mathrm{TM}}$ 
For my parents, Bryan and Gillian 
